\title{
Who's prepared for advocacy? Another inverse law
}

Ian Roberts

\begin{abstract}
Objectives-To examine the characteristics of parents responding to a petition calling for greater efforts to ensure the safety of children as pedestrians and to contrast factors predictive of advocacy with risk factors for child pedestrian injury.
\end{abstract}

Setting-The Auckland region of New Zealand.

Methods-Parents participating in the Auckland Child Pedestrian Injury Study, a community based case-control study, were invited to support a series of recommendations based on the study results, by signing and returning a petition that was to be delivered to the New Zealand Minister for Transport. Characteristics of petitioners were determined by linking their petition responses to the study questionnaires using an unique identifier. The characteristics of petitioners and nonpetitioners were summarised using odds ratios.

Results-31\% of parents signed and returned the petition; $19 \%$ were parents of cases and $36 \%$ were parents of controls. The sociodemographic groups whose children were at the lowest risk of pedestrian injury were the most likely to return the petition. Children in the most disadren of Pacific Island parents were at greatest risk of injury but the parents of these children were the least likely to respond to the petition.

Conclusions-The frequency with which parents advocate for child safety varies inversely with the need for it. Models of health promotion based on community ownership and empowerment alone are unlikely to address the steep socioecnomic gradients in childhood injury mortality.

(Injury Prevention 1995; 1: 152-154)

Department of Community Paediatric Research (C-538), Montreal Children's Hospital, 2300 Tupper, Montreal, Quebec H3H 1P3, Canada

Correspondence to: Dr I Roberts, Child Health Monitoring Unit, Institute of Child Health, 30 Guilford Street, London WC1N 1EH.

Keywords: pedestrian injury, health advocacy, health promotion.

Pedestrian injuries are a leading cause of death and disability in childhood. ${ }^{1}$ Area wide traffic calming schemes are one of the few pedestrian injury prevention strategies for which there is documented evidence of efficacy. ${ }^{2}$ Traffic calmvantaged socioeconomic group and child-

ing schemes aim to reduce the speed of vehicles by using physical measures such as speed humps or the redesign of the street space. ${ }^{3}$ Preston reviewed 19 studies of traffic calming and found injury reductions ranging between $14 \%$ and $83 \%{ }^{4}$ Evaluation of the British Urban Safety Project demonstrated a 13\% reduction in traffic injuries attributable to the scheme. $^{5}$

In New Zealand, traffic calming is implemented after a request by local residents and is paid for out of local authority funds. ${ }^{6}$ Because funds are limited, and there are often a large number of competing requests for funding, a successful application for traffic calming usually follows an intense period of resident lobbying. Residents requesting traffic calming must apply to their local community boards, who normally require proof that the request is supported by the majority of residents in the street. This proof usually takes the form of a residents' petition. In this way, the willingness and ability of members of the community to advocate for child safety becomes an important determinant of the safety of the local environment.

In this paper, data from the Auckland Child Pedestrian Injury Study were used to examine the characteristics of parents responding to a petition calling for greater efforts to ensure the safety of their children as pedestrians. The characteristics of parents taking on this advocacy role are compared with the sociodemographic risk factors for child pedestrian injury.

\section{Methods}

The Auckland Child Pedestrian Injury Study was a community based case-control study, conducted in the Auckland region of New Zealand, between January 1992 and March 1994. The results of this study have been presented in detail elsewhere. ${ }^{7}$ After data analysis and preparation of scientific reports, all parents participating in the study were sent a two page report outlining the major study findings, their implications for prevention, and a summary of the recommendations arising from the study. Parents were invited to support these recommendations by signing and returning a petition to the New Zealand Minister for Transport. The report, recommendations, and petition are available from the author on request.

In the case-control study, each questionnaire was coded with an unique identifier after all 
identifying information had been removed. The stamped addressed return envelope for the petition was identified with the same unique identifier so that the characteristics of petitioners could be determined by linking the petition response to the study questionnaire. Parents who did not return the petition were classified as non-petitioners. The characteristics of petitioners and non-petitioners are summarised using odds ratios. The odds ratio for the petition response is the ratio of the odds of a parent in a given category responding to the petition compared with the baseline category. Both the main case-control study and the study reported in this paper were approved by the regional health authority ethics committee.

\section{Results}

Of the 737 parents invited to sign and return the petition, 258 were parents of cases and 479 were parents of controls. Twenty two invitations were returned by the post office because the parent had changed address. Of the 715 remaining parents, 220 returned a signed petition, a return rate of $31 \%$. In 41 of the returned petitions, there was more than one signature, so that the total number of signatures was 289 . Table 1 contrasts the sociodemographic risk factors for child pedestrian injury with the characteristics of petitioners. The sociodemographic groups whose children were at lowest risk were the most likely to return the petition. Children in the most disadvantaged socioeconomic group, and children of Pacific Island parents were at greatest risk of injury, yet parents in these groups were the least likely to repond to the petition. Nineteen per cent (48/258) of the parents of cases returned the petition compared with $36 \%(171 / 479)$ of parents of controls. Table 2 examines the characteristics of petition responders after excluding the parents of children who were cases in the study. These analyses were undertaken to determine whether the factors predictive of low petition response were simply the characteris-

Table 1 Pedestrian injury odds ratio and petitioning odds ratio for sociodemographic variables

\begin{tabular}{|c|c|c|c|c|c|c|}
\hline Variable & $\begin{array}{l}\text { Cases } \\
(n=258)\end{array}$ & $\begin{array}{l}\text { Controls } \\
(n=479)\end{array}$ & $\begin{array}{l}\text { Injury odds ratio } \\
(95 \% \text { CI })\end{array}$ & $\begin{array}{l}\text { Petiti } \\
\text { Yes }\end{array}$ & $\begin{array}{c}\text { oner } \\
\text { No }\end{array}$ & $\begin{array}{l}\text { Response odds ratio } \\
(95 \% \text { CI) }\end{array}$ \\
\hline $\begin{array}{l}\text { Socioeconomic po } \\
\text { I, II, III } \\
\text { IV, V } \\
\text { VI and others }\end{array}$ & $\begin{array}{l}\text { osition } \\
38 \\
111 \\
109\end{array}$ & $\begin{array}{l}126 \\
225 \\
128\end{array}$ & $\begin{array}{l}1.00 \\
1.64(1.04 \text { to } 2.57) \\
2.82(1.77 \text { to } 4.51)\end{array}$ & $\begin{array}{r}64 \\
110 \\
45\end{array}$ & $\begin{array}{l}100 \\
226 \\
192\end{array}$ & $\begin{array}{l}1.00 \\
0.76(0.51 \text { to } 1.14) \\
0.37(0.23 \text { to } 0.59)\end{array}$ \\
\hline $\begin{array}{l}\text { Ethnic group } \\
\text { Maori } \\
\text { Pacific Island } \\
\text { Other }\end{array}$ & $\begin{array}{r}69 \\
85 \\
104\end{array}$ & $\begin{array}{r}85 \\
85 \\
309\end{array}$ & $\begin{array}{l}2.41(1.61 \text { to } 3.62) \\
2.97(2.01 \text { to } 4.39) \\
1.00\end{array}$ & $\begin{array}{r}23 \\
21 \\
175\end{array}$ & $\begin{array}{l}131 \\
149 \\
238\end{array}$ & $\begin{array}{l}0.24(0.14 \text { to } 0.40) \\
0.19(0.11 \text { to } 0.32) \\
1.00\end{array}$ \\
\hline $\begin{array}{l}\text { Sole parent } \\
\text { Yes } \\
\text { No }\end{array}$ & $\begin{array}{r}73 \\
185\end{array}$ & $\begin{array}{r}96 \\
383\end{array}$ & $\begin{array}{l}1.57(1.09 \text { to } 2.27) \\
1.00\end{array}$ & $\begin{array}{r}34 \\
136\end{array}$ & $\begin{array}{l}136 \\
382\end{array}$ & $\begin{array}{l}0.52(0.33 \text { to } 0.80) \\
1.00\end{array}$ \\
\hline $\begin{array}{l}\text { Home owner } \\
\text { No } \\
\text { Yes }\end{array}$ & $\begin{array}{l}139 \\
119\end{array}$ & $\begin{array}{l}140 \\
339\end{array}$ & $\begin{array}{l}2.83(2.04 \text { to } 3.92) \\
1.00\end{array}$ & $\begin{array}{r}45 \\
174\end{array}$ & $\begin{array}{l}234 \\
284\end{array}$ & $\begin{array}{l}0.31(0.21 \text { to } 0.46) \\
1.00\end{array}$ \\
\hline $\begin{array}{l}\text { Access to a car } \\
\text { No } \\
\text { Yes }\end{array}$ & $\begin{array}{r}74 \\
184\end{array}$ & $\begin{array}{r}70 \\
409\end{array}$ & $\begin{array}{l}2.35(1.60 \text { to } 3.46) \\
1.00\end{array}$ & $\begin{array}{r}20 \\
199\end{array}$ & $\begin{array}{l}124 \\
394\end{array}$ & $\begin{array}{l}0.32(0.19 \text { to } 0.54) \\
1.00\end{array}$ \\
\hline $\begin{array}{l}\text { University educat } \\
\text { No } \\
\text { Yes }\end{array}$ & $\begin{array}{l}\text { ated mother } \\
183 \\
70\end{array}$ & $\begin{array}{l}252 \\
219\end{array}$ & $2 \cdot 27(1.61$ to $3 \cdot 20)$ & $\begin{array}{l}107 \\
109\end{array}$ & $\begin{array}{l}328 \\
180\end{array}$ & $\begin{array}{l}0.54(0.39 \text { to } 0.75) \\
1.00\end{array}$ \\
\hline
\end{tabular}

$\mathrm{CI}$ = confidence interval.
Table 2 Petitioning odds ratio for sociodemographic variables with cases excluded

\begin{tabular}{|c|c|c|c|}
\hline \multirow[t]{2}{*}{ Variable } & \multicolumn{2}{|c|}{ Petitioner } & \multirow{2}{*}{$\begin{array}{l}\text { Response odds ratic } \\
\left(95^{\circ} \mathrm{CI}\right)\end{array}$} \\
\hline & Yes & No & \\
\hline $\begin{array}{l}\text { Socioeconomic po } \\
\text { I, II, III } \\
\text { IV, V } \\
\text { VI and others }\end{array}$ & $\begin{array}{l}\text { n } \\
52 \\
88 \\
31\end{array}$ & $\begin{array}{r}74 \\
137 \\
97\end{array}$ & $\begin{array}{l}1.00 \\
0.91(0.57 \text { to } 1.46) \\
0.45(0.26 \text { to } 0.81)\end{array}$ \\
\hline $\begin{array}{l}\text { Ethnic group } \\
\text { Maori } \\
\text { Pacific Island } \\
\text { Other }\end{array}$ & $\begin{array}{r}15 \\
11 \\
145\end{array}$ & $\begin{array}{r}70 \\
74 \\
164\end{array}$ & $\begin{array}{l}0.24(0.13 \text { to } 0.46) \\
0.17(0.08 \text { to } 0.34) \\
1.00\end{array}$ \\
\hline $\begin{array}{l}\text { Sole parent } \\
\text { Yes } \\
\text { No }\end{array}$ & $\begin{array}{r}22 \\
149\end{array}$ & $\begin{array}{r}73 \\
235\end{array}$ & $\begin{array}{l}0.48(0.27 \text { to } 0.82) \\
1.00\end{array}$ \\
\hline $\begin{array}{l}\text { Home owner } \\
\text { No } \\
\text { Yes }\end{array}$ & $\begin{array}{r}29 \\
142\end{array}$ & $\begin{array}{l}111 \\
197\end{array}$ & $\begin{array}{l}0.36(0.22 \text { to } 0.59) \\
1.00\end{array}$ \\
\hline $\begin{array}{l}\text { Access to a car } \\
\text { No } \\
\text { Yes }\end{array}$ & $\begin{array}{r}12 \\
159\end{array}$ & $\begin{array}{r}58 \\
250\end{array}$ & $\begin{array}{l}0.33(0.16 \text { to } 0.65) \\
1.00\end{array}$ \\
\hline $\begin{array}{l}\text { University educat } \\
\text { No } \\
\text { Yes }\end{array}$ & $\begin{array}{c}\text { nother } \\
76 \\
93\end{array}$ & $\begin{array}{l}176 \\
126\end{array}$ & $\begin{array}{l}0.59(0.39 \text { to } 0.87) \\
1.00\end{array}$ \\
\hline
\end{tabular}

tics of cases. The results are essentially the same, showing that irrespective of whether the respondent was a parent of a case, parents in the high risk groups were less likely to respond.

\section{Discussion}

In 1971 Julian Tudor Hart, a general practitioner in South Wales, coined 'the inverse care law', observing that 'the availability of good medical care tends to vary inversely with the need for it in the population served' ${ }^{8}$ The data presented in this study point towards another inverse law - that the willingness or ability to advocate for child safety varies inversely with the need for it. Without exception, the characteristics of parents least likely to take on the advocacy role offered in this study were the same characteristics that identified groups most at risk of child pedestrian injury. These results may go some way towards explaining why in Auckland, and possibly elsewhere, traffic calming and other safety schemes predominate in the more affluent areas.

There are a number of possible explanations for these results. The parents of children at high risk for injury might have disagreed with the study recommendations. The recommendations were based on both the results of our case-control study and a review of the literature. In calling for improved public transport and strategies to reduce vehicle speeds, the recommendations might have been viewed as anti-car. However, the proportion of car owners who supported the study recommendations $(34 \%)$ was more than twice the proportion of those who were not car owners $(14 \%)$. Indeed, the groups in question are likely to have had the most to gain from the strategies suggested.

It is also possible that a higher percentage of parents in the high risk groups may have experienced language or literacy barriers. The report was aimed at a wide audience including key road safety organisations, child health advocacy groups and politicians, and attempted 
to strike a balance between technical detail and readability. Nevertheless, the reading level of the report would have been a barrier for many parents (Flesch Kincaid grade level 12).

In addition, parents in the high risk groups, being disproportionately disadvantaged, undoubtedly had more pressing problems to deal with, in particular those surrounding the need to secure an income, and to feed, clothe, and house the family. There is also some suggestion that parents in the high risk groups are more suspicious of officialdom and were, therefore, reluctant to put their names to a petition to a government minister. According to the interviewers in the case-control study, on many occasions, reassurance that the interviewer was not an employee of the Department of Social Welfare checking on the benefit eligibility was pivotal in securing parental cooperation. These are all plausible explanations and represent considerations that would severely compromise the ability of parents in the high risk groups to advocate for child safety.

It also may be possible that the parents of children in the high risk groups thought it unlikely that a petition to a minister would have any tangible benefit at the level of their locality. Had we suggested petitioning the local community board the results might have been different. The rationale for petitioning the minister was that financially stretched community boards would be powerless to implement traffic calming unless funds were made available from central government. The British Traffic Calming Act of 1992 provides an example of how central government initiatives can facilitate local traffic calming schemes. ${ }^{9}$ Moreover, community boards would be unable to influence broader government policies such as those determining the provision of public transport.

\section{Conclusion}

Community development and empowerment are concepts that are gaining widespread appeal in the 'new' public health. ${ }^{10}$ The Ottawa Charter for Health Promotion equates community empowerment with a community's 'ownership and control ..... of its own endeavours and destinies'. ${ }^{11}$ In the present political climate community empowerment has a strong political connotation. The concept justifies, in the name of health, curtailing state responsibilities in order to increase community control. In this study, it might be reasonable to infer that parents who supported the study recommendations, by signing the study petition, felt that doing so would have some effect. To the extent that they did, these parents felt 'empowered' to effect the change. The message behind these results is that while decentralisation of decision making will undoubtedly benefit some communities, the benefits are unlikely to be distributed equally throughout society. There are steep socioeconomic gradients in child pedestrian injury mortality. In Britain, children in social class $\mathrm{V}$ are over four times more likely to die in a pedestrianmotor vehicle collision than are children in social class $I .^{12}$ If the responsibility for implementing strategies for child pedestrian safety rests solely with parents these gradients are likely to persist, at least in part, because the ability to advocate for child safety varies inversely with the need for it.

This study was funded by the Health Research Council of New Zealand.

1 Pless IB, Verreault R, Arsenault L, Frappier J, Stulginskas $\mathrm{J}$. The epidemiology of road accidents in childhood. $A m \mathcal{F}$ Public Health 1987; 77: 358-60.

2 Towner E, Dowswell T, Jarvis S. Reducing childhood accidents. The effectiveness of health promotion interven accidents. The effectiveness of health promotion interventions: a literature

3 Kjemtrup K, Herrstedt L. Speed management and traffic calming in urban areas in Europe: a historical view. Accid Anal Prev 1992; 24: 57-65.

4 Preston B. Cutting pedestrian casualties; cost-effective ways to make walking safer. London: Transport 2000, 1992.

5 Ward H, Norrie J, Allsop R, Sang A. Urban safety project. the Bristol scheme. London: Department of Transport TRRL, 1989.

6 Roberts I, Norton R, Dunn R. Preventing child pedestrian injuries: pedestrian education or traffic calming. Aust $\mathcal{F}$ Public Health 1994; 18: 209-12.

7 Roberts I, Norton R, Jackson R, Dunn R, Hassall I. Effect of environmental factors on the risk of injury of child environmental factors on the risk of injury of child

pedestrians by motor vehicles. BMf 1995; 310: $91-4$.
8 Hart JT. The inverse care law. Lancet 1971; i: 405-12.

9 Avery JG, Jackson RH. Children and their accidents. London: Edward Arnold, 1993.

10 Peterson AR. Community development in health promotion: empowerment or regulation? Aust $\mathcal{f}$ Public Health 1994; 18: 213-7.

11 World Health Organization. Ottawa charter for health promotion. First International Conference on Health Promotion, Ottawa, Canada, 17-21 November 1986.

12 Woodroffe C, Glickman M, Barker M, Power C. Children, teenagers and health: the key data. Bury St Edmunds, Suffolk, UK: St Edmundsbury Press, 1993. 